Acta vet. scand. $1969,10,193-194$.

Brief communication

\title{
ACTIVE MAMMARY EXCRETION OF N4-ACETYLATED p-AMINOHIPPURIC ACID*)
}

Different excretion patterns were observed for p-aminohippuric acid and its acetylated metabolite in mammary excretion experiments in goats and cows. The excretion of p-aminohippuric acid conformed to passive diffusion of the non-protein bound and un-ionized fraction (Rasmussen 1958, 1966) as described by Miller et al. (1967). 'Thus, the p-aminohippuric acid $\left(\mathrm{pK}_{\mathrm{a}} 3.8\right)$ appeared in ultrafiltrates of milk in concentrations $1 / 4-1 / 10$ of the concentrations in ultrafiltrates of blood plasma. The concentrations of acetylated p-aminohippuric acid $\left(\mathrm{pK}_{\mathrm{a}} 3.9\right)$ in ultrafiltrates of milk were on the other hand equal to or higher than in ultrafiltrates of blood plasma.

Further experiments were conducted by intravenous infusion of acetylated p-aminohippuric acid using the equilibrium technique described by Rasmussen (1958). After acid hydrolysis the concentrations of acetylated p-aminohippuric acid in milk and blood plasma were estimated according to the method described by Bratton \& Marshall (1939). It may be seen from the results listed in Table 1 that the concentrations of acetylated p-aminohippuric acid in milk and in ultrafiltrates of milk are equal to or higher than in plasma (ratio $\mathrm{M} / \mathrm{P}$ ) and ultrafiltrates of plasma (ratio M.Ultr./P.Ultr.), respectively. The theoretical ratios for an equilibrium by passive diffusion were calculated from the formula

$$
\frac{\text { Milk Ultr. }}{\text { Plasma Ultr. }}=\frac{1+10^{\left(\mathrm{pH}_{\text {milk }}-\mathrm{pK}_{\mathrm{a}}\right)}}{1+10^{\left(\mathrm{pH}_{\text {blood }}-\mathrm{pK}_{\mathrm{a}}\right)}}
$$

and are listed in the last column of Table 1 . The experimentally found ratios M.Ultr./P.Ultr. are $3-30$ times higher than the calculated. The data presented in Table 1 also demonstrate that

*) Supported by a grant from Statens almindelige Videnskabsfond. 
Table 1. Concentrations of acetylated p-aminohippuric acid in milk and blood plasma and in ultrafiltrates of milk and blood plasma.

\begin{tabular}{|c|c|c|c|c|c|c|c|c|}
\hline \multirow{2}{*}{ Animal } & \multirow{2}{*}{$\begin{array}{c}\text { Plasma } \\
\mu \mathrm{g} / \mathrm{ml}\end{array}$} & \multirow{2}{*}{$\begin{array}{c}\text { Milk } \\
\mu \mathrm{g} / \mathrm{ml}\end{array}$} & \multirow{2}{*}{$\begin{array}{l}\text { Ratio } \\
\mathrm{M} / \mathrm{P}\end{array}$} & \multicolumn{2}{|c|}{ Ultrafiltrate of } & \multirow{2}{*}{$\begin{array}{c}\text { M. Ultr./ } \\
\text { P.Ultr. } \\
\text { experimental }\end{array}$} & \multirow{2}{*}{$\begin{array}{l}\text { Milk } \\
\mathrm{pH}\end{array}$} & \multirow{2}{*}{$\begin{array}{l}\text { M. L'ltr./ } \\
\text { P. L'ltr. } \\
\text { theoretical }\end{array}$} \\
\hline & & & & $\begin{array}{c}\text { plasma } \\
\mu \mathrm{g} / \mathrm{ml}\end{array}$ & $\underset{\mu \mathrm{milk} / \mathrm{ml}}{\stackrel{\mathrm{ml}}{ }}$ & & & \\
\hline Cow 93 & 2.0 & 8.2 & 4.1 & 2.0 & 7.5 & 3.8 & 6.75 & 0.20 \\
\hline Cow 93 & 2.0 & 7.5 & 3.8 & 2.0 & 6.9 & 3.5 & 6.65 & 0.16 \\
\hline Goat 40 & 3.7 & 12.5 & 3.4 & 3.7 & 12.5 & 3.4 & 6.60 & 0.16 \\
\hline Goat 40 & 8.8 & 27.0 & 3.1 & 8.3 & 27.0 & 3.2 & 6.50 & 0.10 \\
\hline Cow 93 & 9.4 & 17.5 & 1.9 & 9.4 & 17.5 & 1.9 & 6.70 & 0.16 \\
\hline Cow 93 & 9.4 & 16.3 & 1.7 & 9.4 & 16.3 & 1.7 & 7.00 & 0.32 \\
\hline Goat 36 & 14.8 & 29.5 & 2.0 & 13.5 & 27.1 & 2.0 & 7.40 & 0.79 \\
\hline Cow 83 & 21.1 & 17.3 & 0.8 & 18.4 & 17.3 & 0.9 & 6.60 & 0.14 \\
\hline Goat 40 & 23.6 & 37.8 & 1.6 & 19.6 & 37.8 & 1.9 & 6.70 & 0.20 \\
\hline
\end{tabular}

the milk-to-plasma ratios decrease with increasing concentrations of acetylated p-aminohippuric acid in plasma. Thus, the results indicate that an active saturable excretory process is involved in the mammary excretion of acetylated p-aminohippuric acid.

\section{Folke Rasmussen}

Department of Pharmacology and Toxicology,

The Royal Veterinary and Agricultural University,

Copenhagen, Denmark

\section{REFERENCES}

Bratton, A. C. \& E. K. Marshall: A new coupling component for sulfanilamide determination. J. biol. Chem. 1939, 128, 537-550.

Miller, G. E., N. C. Banerjee \& C. M. Stowe: Diffusion of certain weak organic acids and bases across the bovine mammary gland membrane after systemic administration. J. Pharmacol. exp. Ther. 1967, 157, 245-253.

Rasmussen, Folke: Mammary excretion of sulphonamides. Acta pharmacol. (Kbh.) 1958, 15, 139-148.

Rasmussen, Folke: Studies on the mammary excretion and absorption of drugs. Thesis. Copenhagen 1966. 